\title{
Using geochronology to reconstruct the evolution of particulate phosphorus inputs during the past century in the Papeete Lagoon (French Polynesia)
}

\author{
Pierre HARRIS $^{\mathrm{a}}$, Renaud FICHEZ ${ }^{\mathrm{a}}$, Jean-Michel FERNANDEZ ${ }^{\mathrm{a}}$, Han GOLTERMAN $^{\mathrm{b}}$, Christian BADIE $^{\mathrm{c}}$ \\ ${ }^{\text {a }}$ Centre IRD de Nouméa, BP A5, Nouméa cedex, New Caledonia \\ ${ }^{\mathrm{b}}$ Association Leiden Camargue, 5, chemin de Tintarlot, 13200 Arles, France \\ ${ }^{\mathrm{c}}$ LESE, BP 519, Papeete, Tahiti, French Polynesia
}

Received 30 May 2000; revised 4 September 2000; accepted 6 September 2000

\begin{abstract}
During the past century, the sediment deposition rate has been assessed by measuring excess ${ }^{210} \mathrm{~Pb}$ activity in a sediment core sampled in the harbour area of the Papeete Lagoon (Tahiti, French Polynesia). Dated sediment samples were analysed following a sequential extraction method to quantify five sedimentary phosphorus pools: loosely sorbed or exchangeable phosphorus, ferric iron-bound phosphorus, authigenic calcium carbonate associated phosphorus, detrital apatite and detritic inorganic phosphorus, and organic phosphorus. Results from sediment dating showed the core to cover the period from 1865 to 1995, with a sharp change around 1957 corresponding to a doubling in sediment deposition rates. From the bottom to the top of the core, concentrations decreased for authigenic calcium carbonate-associated phosphorus, were almost constant for exchangeable phosphorus, and increased significantly for iron-bound phosphorus, detritic inorganic phosphorus and organic phosphorus. As a consequence, the calculated phosphorus total accumulation rate was multiplied by four from top to bottom. Those trends were related to modifications in the relative importance of the five phosphorus reservoirs, especially for organic phosphorus, which contribution increased to $30 \%$ of total phosphorus in recent sediments. From the sequential extraction approach it is possible to estimate that phosphorus with a terrestrial origin represented $54 \%$ of total phosphorus in recent sediment, while it only represented $30 \%$ at the beginning of the century. Present particulate phosphorus inputs were also assessed from a sediment trap approach and a budget of phosphorus burial efficiency is proposed. (C) 2001 Ifremer/CNRS/IRD/Éditions scientifiques et médicales Elsevier SAS
\end{abstract}

Résumé-Reconstitution géochronologique de l'évolution des apports en phosphore particulaire durant le dernier siècle dans le lagon de Papeete (Polynésie française). Le taux de sédimentation a été évalué par la mesure de l'activité du ${ }^{210} \mathrm{~Pb}$ en excès dans une carotte de sédiment prélevée dans la zone portuaire du lagon de Papeete (Tahiti, Polynésie française). Les échantillons de sédiments datés ont été soumis à une extraction séquentielle afin de déterminer cinq fractions sédimentaires de phosphore : faiblement adsorbé ou échangeable, associé au fer ferrique, lié au carbonate de calcium authigène, détritique et organique. Les résultats de datation montrent que la carotte couvre la période 1865-1996, avec un changement majeur vers 1957 correspondant à un doublement du taux de sédimentation. Entre la base et le haut de la carotte, les concentrations diminuent pour le phosphore lié au carbonate de sodium, restent

*Correspondence and reprints: fax: +687 264326.

E-mail address: fichez@noumea.ird.nc (R. FICHEZ).

(C) 2001 Ifremer/CNRS/IRD/Éditions scientifiques et médicales Elsevier SAS. Tous droits réservés

S0399178400011233/FLA 
constantes pour le phosphore faiblement échangeable, et augmentent pour le phosphore associé au fer ferrique, le phosphore détritique et organique. Les augmentations conjointes du taux de sédimentation et de la concentration en phosphore ont pour conséquence de multiplier par quatre le taux d'accumulation de phosphore total. Ces tendances correspondent à des modifications importantes de la contribution relative de chaque fraction, en particulier pour le phosphore organique qui représente plus de 30\% du phosphore total dans les sédiments récents. Sur la base des extractions séquentielles, il est possible d'estimer que le phosphore d'origine terrestre représente $54 \%$ du phosphore total dans les sédiments récents, contre seulement 30\% au début du siècle. Le dépôt actuel de phosphore particulaire a également été évalué au moyen de pièges à particules, et un bilan de la diagénèse du phosphore est présenté. (C) 2001 Ifremer/CNRS/IRD/Éditions scientifiques et médicales Elsevier SAS

\section{geochronology / phosphorus / sediment / coral reef lagoon}

\section{géochronologie / phosphore / sédiment / lagons coralliens}

\section{INTRODUCTION}

Tropical coral reef environments are increasingly confronted with environmental alteration due to human activities (Grigg and Dollar, 1990; Gabric and Bell, 1993). The small developing islands in the tropical Pacific with limited land surfaces and increasing population pressure have been subject to recent human-induced environmental changes (Kenchington and Bleakley, 1994; Zan, 1994). In Tahiti, French Polynesia, the lagoon surrounding the city of Papeete has been subject to serious anthropogenic modifications because of extensive economic and urban development during the second half of the last century (Gabrié, 1995a, b).

However, precisely assessing the extent of environmental changes in such an environment is a critical issue because of the paucity and heterogeneity of existing data sets. Fortunately, undisturbed sediment can be dated using radioisotopic clocks, therefore providing a very significant source of historical information thanks to their capacity to record past environmental conditions (ValetteSilver, 1993; Carignan et al., 1994). Considering phosphorus, sediment cores have been used to provide qualitative interpretation of changes in phosphorus concentrations and deposition rates either in lakes or in marine environments (Schelske et al., 1988; Cornwell et al., 1996; Rippey and Anderson, 1996; Louchouarn et al., 1997; Vink et al., 1997; Gerritse et al., 1998a, b).

The aim of the present work was to examine what information could be gained from the study of phosphorus accumulation rates in a sediment core sampled in Papeete Harbour. When combining sediment geochronology with the study of the various forms of sedimentary phosphorus species, it appeared possible to reconstruct the history of phosphorus inputs during the past century. Furthermore, we wanted to assess the potential for using sequential extraction to separate the various phosphorus reservoirs bound to particle phases in marine sediments, and their respective accumulation rate over time (Ruttenberg, 1992).

Therefore, in this paper, sediment chronology was combined with the analysis of five different phosphorus reservoirs in order to address two questions: 1) is it possible to reconstruct past phosphorus inputs in coral reef lagoons? 2) What information is provided by the use of a phosphorus sequential extraction approach? In addition, results from the sedimentary record approach were compared with sediment trap assessment of present particulate phosphorus flux and conclusions regarding phosphorus burial rate in a coral barrier reef lagoon subject to urban development are provided.

\section{MATERIAL AND METHODS}

\subsection{Study site}

The extension of Papeete and its harbour (figure 1) was boosted during the early sixties when the French Government decided to develop nuclear testing facilities on the atolls of Mururoa and Fangataufa. Population growth resulted in an increase from 30000 inhabitants in 1945 to 120000 inhabitants in 1998. The building of harbour facilities began in 1938 and culminated in 1963-1966 with a total of almost $100000 \mathrm{~m}^{2}$ of land reclaimed on the sea, coral platforms and barrier reef. Such modifica- 


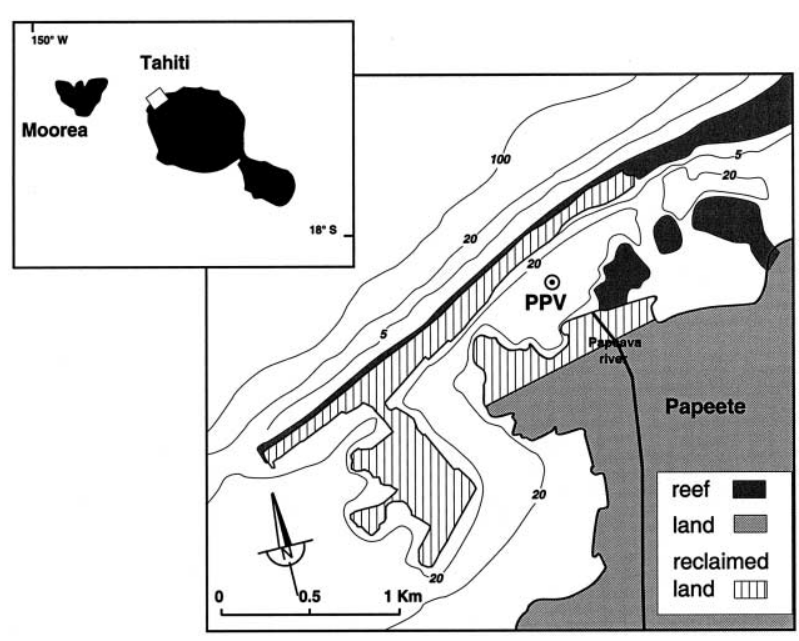

Figure 1. Map of the Tahiti lagoon showing the location of the core PPV sampled at the mouth of the Papeava River.

tions of the harbour and the coastline strongly modified water exchanges between the open ocean and the small lagoon, the main features being a 2-km long sea wall built on the barrier reef and blocking inputs of ocean water over the reef. As a consequence, the rates of lagoon water renewal and water circulation have been greatly reduced in this part of the lagoon. Moreover, the Papeava River has been delivering an increasing load of terrigenous and anthropogenic material to the lagoon because of extensive soil erosion and release of mostly untreated waste waters due to constant increase in population (Fichez et al., 1997; Harris, 1998). Unfortunately, no historical data are available on the evolution of river discharge, and associated dissolved and particulate transport (Aubanel et al., 1998), making sedimentary archives especially valuable.

\subsection{Sampling and analysis}

To reconstruct the evolution of anthropogenic effects during the last century, a sediment core was sampled in January 1996 at the mouth of the Papeava River (figure 1) by diving at a depth of $33 \mathrm{~m}$ on a muddy bottom. We used a PVC corer with a length of $1 \mathrm{~m}$ and a diameter of $25 \mathrm{~cm}$ that could be open in two halves. The whole core length was cut in sediment slices of $1 \mathrm{~cm}$ thickness and sediment sub-samples were oven dried or freeze dried depending on the projected analysis. The ${ }^{210} \mathrm{~Pb}$ activity was determined on samples separated by $2 \mathrm{~cm}$ between 1 and
$62 \mathrm{~cm}$ depth $(1-2,3-4, . ., 61-62 \mathrm{~cm})$. Other analyses were carried out, each on $1 \mathrm{~cm}$ sample between 0 and $10 \mathrm{~cm}$ depth and on sediment samples separated by $4 \mathrm{~cm}$ below $10 \mathrm{~cm}(13-14,17-18, \ldots, 57-58 \mathrm{~cm})$.

Sediment accumulation rates were determined using the decrease of excess ${ }^{210} \mathrm{~Pb}$ activity. The ${ }^{210} \mathrm{~Pb}$ was determined by measuring its granddaughter ${ }^{210} \mathrm{Po}$ on an alpha spectrometer, assuming secular equilibrium with ${ }^{210} \mathrm{~Pb}$ (Teksöz et al., 1991) and following the standardised methods of Flynn (1968), modified by Nittrouer et al. (1979) and Serra et al. (1991). Excess ${ }^{210} \mathrm{~Pb}$ was determined as total ${ }^{210} \mathrm{~Pb}$ minus ${ }^{226} \mathrm{Ra}$ supported ${ }^{210} \mathrm{~Pb},{ }^{226} \mathrm{Ra}$ being measured on a gamma spectrometer. Sediment accumulation rates were determined using the equations of Faure (1986) on fits of straight-line segments of the log-linear profile of excess ${ }^{210} \mathrm{~Pb}$. Sediment depth was expressed in mass accumulated sediment in grams per centimetre rather than in centimetres in order to compensate for sediment compacting effects (Bollhöfer et al., 1994). Age and confidence limits for each sediment level were derived from the linear fit determination of the average accumulation rates (Robbins and Herche, 1993).

Carbonate content was determined by weighing dried sediment samples before and after acetic acid attack as described by Loring and Rantala (1992). The acetic method was chosen because it is one of the weakest chemical treatments that can be used to dissolve calcium carbonate (Loring and Rantala, 1988). The proportion of material removed by this extraction is operationally defined as the carbonate fraction of the sediment, the remaining fraction is called the residual fraction (Unep/ IOC/IAEA, 1995). Organic carbon was analysed on a Perkin-Elmer 2400 CHN elemental analyser after removal of carbonate by $\mathrm{HCl}$ fumes according to Yamamuro and Kayanne (1995).

Phosphorus studies were based on the sequential extraction procedure developed by Ruttenberg (1992). This method quantifies five sediment phosphorus pools: loosely sorbed or exchangeable phosphorus $\left(P_{\mathrm{ex}}\right)$ extracted by $\mathrm{MgCl}_{2}$ at $\mathrm{pH} 8$, ferric iron-bound phosphorus $\left(P_{\mathrm{Fe}}\right)$ extracted by citrate dithionite bicarbonate buffer at $\mathrm{pH}$ 7.6, authigenic calcium carbonate associated phosphorus $\left(P_{\text {auth }}\right)$ extracted by acetate buffer at $\mathrm{pH} 4$, detrital apatite and detritic inorganic phosphorus $\left(P_{\text {det }}\right)$ extracted by $1 \mathrm{M} \mathrm{HCl}$, and organic phosphorus $\left(P_{\text {org }}\right)$ after removal by ignition at $550{ }^{\circ} \mathrm{C}$. Phosphorus was determined by colorimetric analysis (Koroleff, 1976; Lucotte et 
d'Anglejan, 1985) and concentrations expressed in micrograms of phosphorus per gram of dried sediment weight $\left(\mu \mathrm{g} \mathrm{g}^{-1}\right)$.

Sedimentary phosphorus deposition rate was determined by multiplying phosphorus concentration by sediment accumulation rate, and was expressed as micrograms per centimetre per year. Sedimentary phosphorus deposition rate was compared with the vertical particulate phosphorus flux reaching the sediment-water interface as determined by sediment traps. A sediment trap including three collectors $(30 \mathrm{~cm}$ high and $8 \mathrm{~cm}$ in diameter) for collection of triplicate samples was deployed at the same location as the core (33 $\mathrm{m}$ depth), $3 \mathrm{~m}$ above the bottom for $48 \mathrm{~h}$ each month during the period September 1995 to October 1996. Due to the very calm waters enclosed within this urbanised lagoon system, we considered resuspension contribution at $3 \mathrm{~m}$ above the bottom to be very limited.

\section{RESULTS}

\subsection{Geochronology}

Excess ${ }^{210} \mathrm{~Pb}$ activities were plotted versus accumulated sediment weight (figure 2). Homogeneous activities in surface sediment are related to bioturbation effects, which proved to be constrained to the top $8 \mathrm{~cm}\left(6.8 \mathrm{~g} \mathrm{~cm}^{-2}\right)$ of the core. Below this sediment mixing layer, we obtained two $\log$-linear curves with an intersection at $35 \mathrm{~g} \mathrm{~cm}^{-2}$. In the upper part, the linear fit gave a coefficient of determination $\left(R^{2}\right)$ of 0.87 and the equation was $y=-0.035 x$ 0.80 (where $y$ is the accumulated sediment weight in $\mathrm{g} \mathrm{cm}^{-2}$ and $x$ is excess ${ }^{210} \mathrm{~Pb}$ activity in $\mathrm{mBq} \mathrm{g}^{-1}$ ). In the lower part, the linear fit gave a $R^{2}$ of 0.87 and the equation was $y=-0.078 x+0.52$. Considering the decay constant of ${ }^{210} \mathrm{~Pb}\left(0.03114\right.$ year $\left.^{-1}\right)$, it was possible to calculate the two accumulation rates. Above $35 \mathrm{~g} \mathrm{~cm}^{-2}$, which corresponded to a sediment depth of $35 \mathrm{~cm}$, the accumulation rate was $0.90 \pm 0.09 \mathrm{~g} \mathrm{~cm}^{-2}$ year $^{-1}$. Below $35 \mathrm{~g} \mathrm{~cm}^{-2}$, the accumulation rate was $0.40 \pm 0.05 \mathrm{~g} \mathrm{~cm}^{-2}$ year $^{-1}$. The significant change in sediment accumulation rates measured at $35 \mathrm{~cm}$ depth therefore occurred approximately in $1957 \pm 4$ years. It must be acknowledged that the surface mixed layer can be an additional source of error for dating. However, when applying the more recent accumulation rate on that

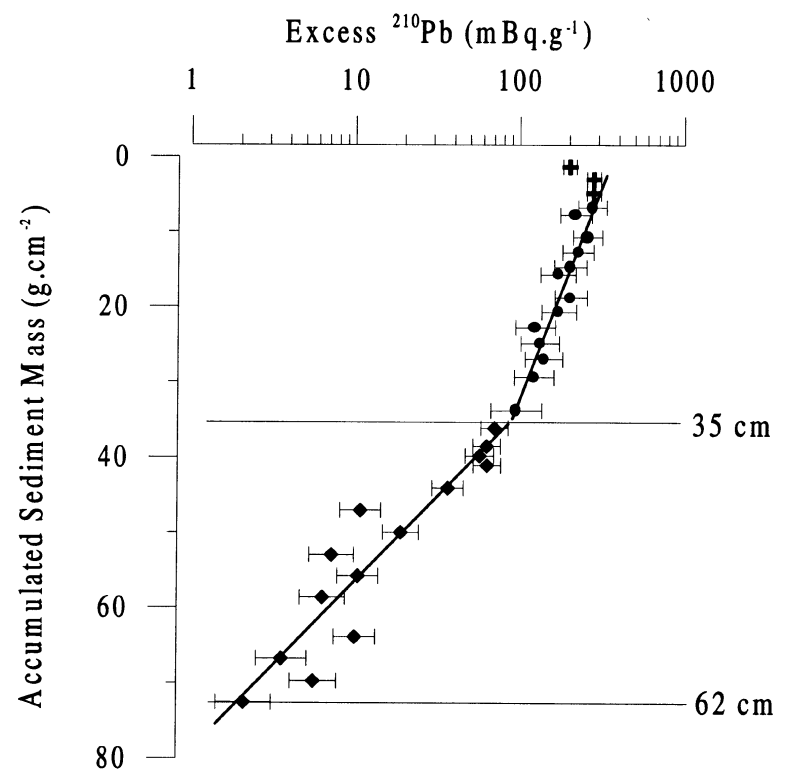

Figure 2. Geochronology based on log of excess ${ }^{210} \mathrm{~Pb}$ (and standard error bars) plotted against accumulated sediment weight. Surface samples (top $6 \mathrm{~cm}$ ) corresponded to a bioturbated layer (+). Average accumulation rates calulated from linear regression are $0.90 \pm$ $0.09 \mathrm{~g} \mathrm{~cm}^{-2}$ year $^{-1}$ for the upper part of the core $(\bullet)$, and $0.40 \pm$ $0.05 \mathrm{~g} \mathrm{~cm}^{-2}$ year $^{-1}$ for the lower part of the core $(\diamond)$.

limited layer we obtained a period of no more than 7.6 years, which would not grossly affect dating precision.

\subsection{Carbonate distribution}

The carbonate fraction was plotted against the year (figure 3). Prior to 1930, the sediment was composed of 75\% carbonate; from 1930 to 1965 we observed a transition zone with a decrease in carbonate from 70 to $25 \%$; after 1965 , carbonate accounted for 20 to $25 \%$ of the sediment. Due to the basaltic nature of Tahiti Island and the absence of an emerged carbonate platform, carbonate in the sediment core is exclusively originating from autochthonous marine carbonate production. The non-carbonate fraction, which accounted for 75 to $80 \%$ of the sediment in the upper and most recent layer, is formed of terrigenous inputs mainly in the form of basaltic sediments that are especially rich in silica. Therefore, it can be estimated that terrigenous inputs increased from 25 to $75 \%$ during the 1930-1957 period. It must be further acknowledged that bioturbation is 


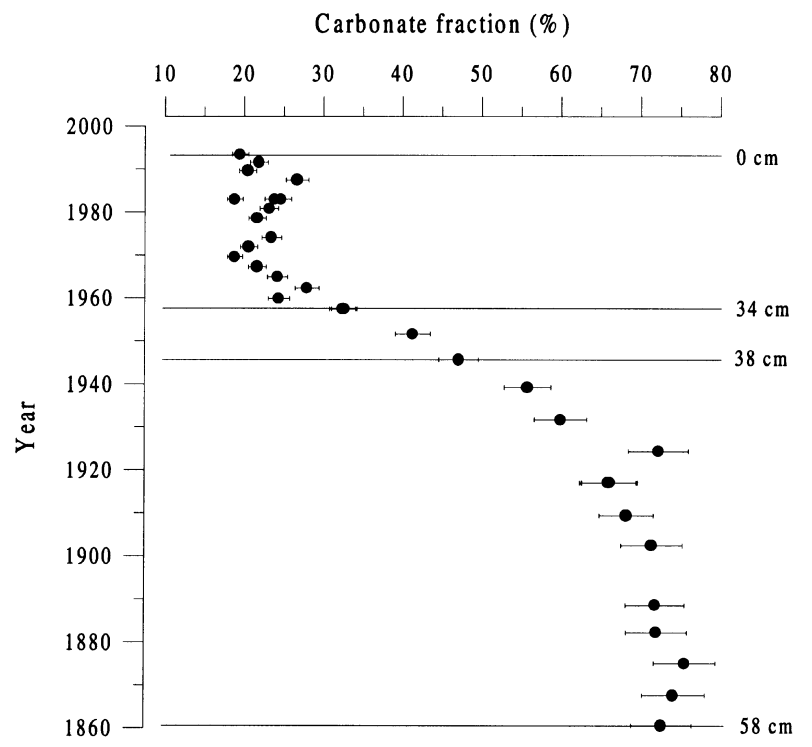

Figure 3. Average carbonate content in percent (and standard error bars) plotted against year for the period 1865-1995.

responsible for sediment homogenisation in the top sediment layer, hence generating a downward transport of recently deposited material. This transport process will result in a bias in tracer distribution, as a variation in tracer concentrations will appear older than the actual occurrence of an environmental change (Boudreau, 1997).

\subsection{Phosphorus speciation}

Phosphorus concentrations in dried sediment are plotted against ${ }^{210} \mathrm{~Pb}$ year (figure 4 ). When considering the five phosphorus pools determined by sequential extraction we observed different patterns. Exchangeable phosphorus $\left(P_{\mathrm{ex}}\right)$ showed no strong temporal variation. Iron bound phosphorus concentration $\left(P_{\mathrm{Fe}}\right)$ increased from 50 to $300 \mu \mathrm{g} \mathrm{g}^{-1}$ between 1930 and 1960 and stayed constant afterward. Authigenic carbonate phosphorus concentration $\left(P_{\text {auth }}\right)$ showed an opposite trend as it decreased from more than $400 \mu \mathrm{g} \mathrm{g}^{-1}$ at the beginning of the century to $200 \mu \mathrm{g} \mathrm{g}^{-1}$ after 1960. Detritic phosphorus $\left(P_{\text {det }}\right)$ concentration increased from $200 \mu \mathrm{g} \mathrm{g}^{-1}$ prior to 1930 to more than $400 \mu \mathrm{g} \mathrm{g}^{-1}$ after 1960. Finally, organic phosphorus concentration $\left(P_{\text {org }}\right)$ increased from $100 \mu \mathrm{g} \mathrm{g} \mathrm{g}^{-1}$ prior to 1930 to more than $400 \mu \mathrm{g} \mathrm{g}^{-1}$ after 1960 .

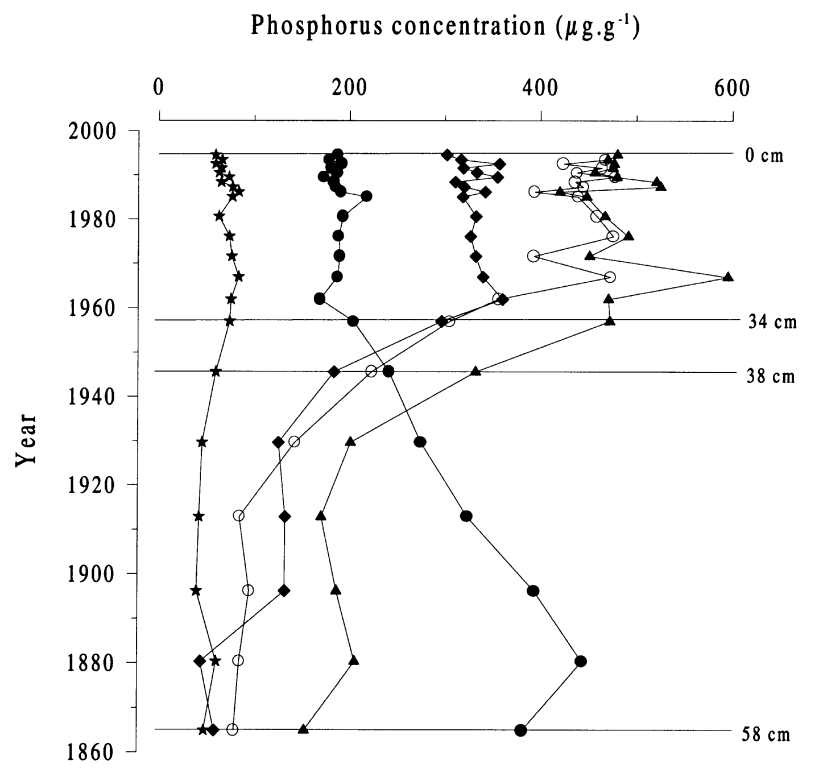

Figure 4. Evolution of phosphorus pools in sediments extracted by the SEDEX method during the period 1865-1995: $P_{\mathrm{ex}}(\star), P_{\mathrm{Fe}}(\diamond), P_{\text {auth }}$ $(\bullet), P_{\text {det }}(\mathbf{\Delta}), P_{\text {org }}(\bigcirc)$.

These results can be illustrated by plotting the respective distribution of phosphorus among each pool of phosphorus at three typical different core levels (figure 5). For year $1885 \pm 16$ years the phosphorus pool was strongly dominated by $P_{\text {auth }}$ associated to carbonate, whereas $P_{\text {org }}$ was about $10 \%$ and $P_{\mathrm{Fe}}$ only $5 \%$ of total phosphorus. This is consistent with our results on carbonate concentrations showing that carbonate inputs were dominant in the bottom layers of the core due to low terrigenous inputs. In the transition zone (1930-1960), a decrease in carbonatebound phosphorus and an increase in organic, iron-bound and residual inorganic phosphorus was observed. Over the period 1957-1995, sediment phosphorus was dominated by $P_{\mathrm{det}}\left(33 \%\right.$ of the total), $P_{\mathrm{org}}(28 \%)$, and $P_{\mathrm{Fe}}$ $(21 \%)$.

Additionally, the $C_{\text {org }}$ vs. $P_{\text {org }}$ ratio evolution was represented (figure 6). The ratio, close to 80 at the bottom of the core, decreased to a stable value of around 50 from 1945 to present demonstrating a clear change in the nature of deposited organic material.

\subsection{Phosphorus accumulation rates}

The evolution of total phosphorus inputs can be assessed when plotting the phosphorus accumulation rate, ex- 

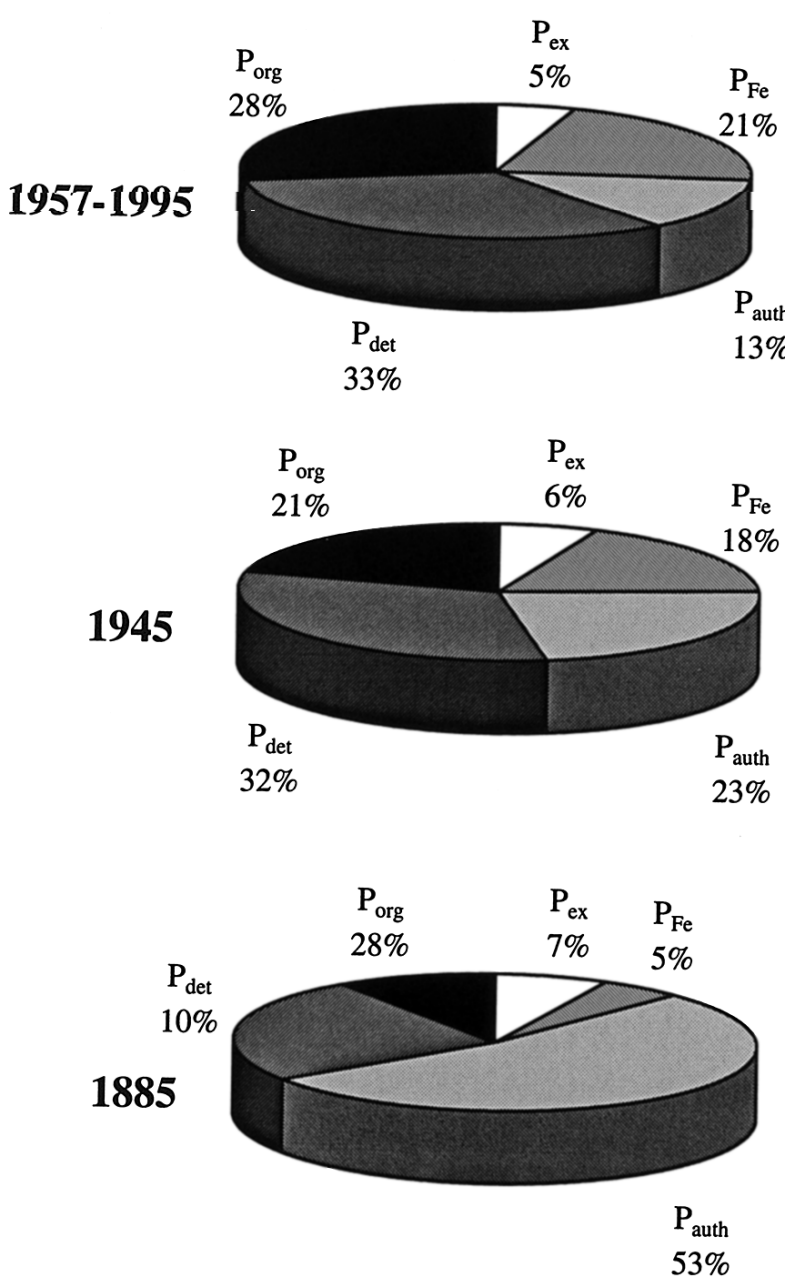

Figure 5. Distribution of the five phosphorus reservoirs in percentage of total phosphorus for year 1885, 1945 and an average over the period 1957-1995.

pressed as $\mu \mathrm{g} \mathrm{cm}^{-2}$ year-1, versus ${ }^{210} \mathrm{~Pb}$ year (figure 7 ). Looking from the past to the present we observed that $P_{\text {tot }}$ accumulation rate increased from $300 \mu \mathrm{g} \mathrm{cm}^{-2}$ year $^{-1}$ at the bottom of the core (age 1865) to a maximum of $1400 \mu \mathrm{g} \mathrm{cm}^{-2}$ year $^{-1}$ after 1960. Unlike the distribution of concentrations, and due to the conjunction of increased phosphorus concentrations and the sudden significant increase in sediment deposition rate, almost no transition zone is observed and there is a sharp increase between two adjacent sediment levels dated 1945 and 1957, respectively.

The efficiency of phosphorus retention by sediments was evaluated by comparing the phosphorus accumulation

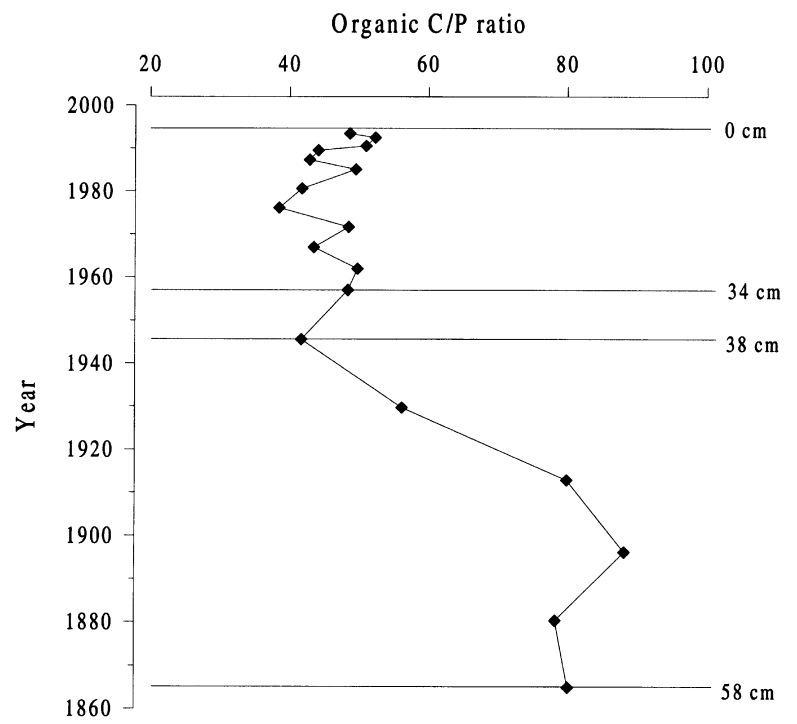

Figure 6. Evolution of the organic carbon versus organic phosphorus ratio (w/w) during the period 1865-1995.

rate calculated for the past four decades with phosphorus vertical flux obtained from sediment traps in 1995-1996 (Fichez and Harris, unpublished data). Average total phosphorus flux calculated over a thirteen months period was $2350 \pm 300 \mu \mathrm{g} \mathrm{cm}^{-2}$ year $^{-1}$, whereas average total phosphorus accumulation rate in the top $30 \mathrm{~cm}$ of the

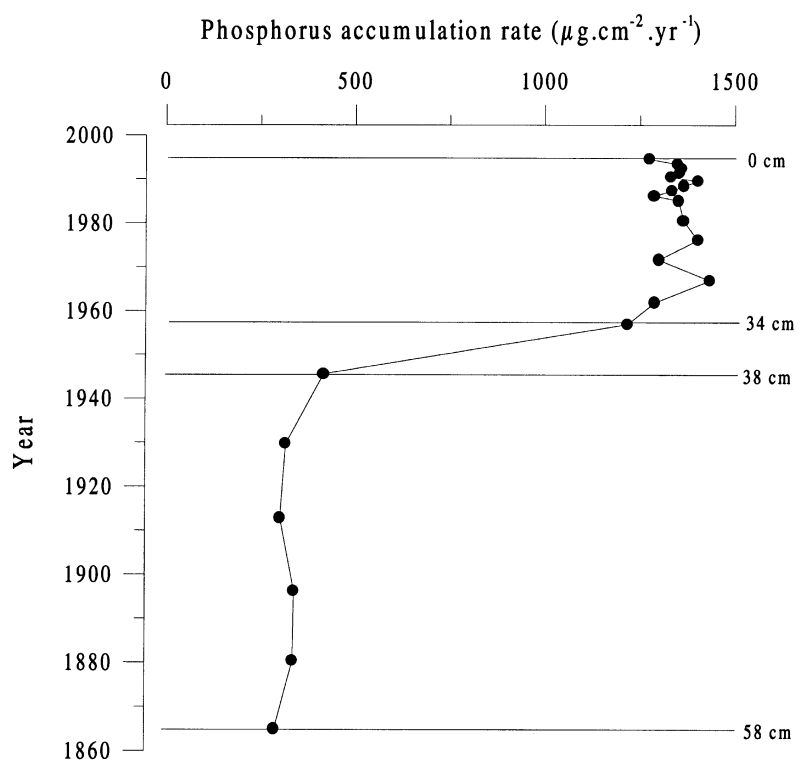

Figure 7. Total phosphorus accumulation rate in $\mu \mathrm{g} \mathrm{cm}^{-2}$ year during the period 1865-1995. 
core was $1400 \pm 50 \mu \mathrm{g} \mathrm{cm}^{-2}$ year $^{-1}$. From these results it is possible to roughly estimate a minimum phosphorus burial efficiency of $60 \pm 10 \%$.

\section{CONCLUSION}

Sediment deposition in the Papeete Lagoon at the mouth of the Papeava River was considerably modified during the 1930-1960 period. The sediment in the bottom layers of the core is mainly composed of carbonate of marine origin, deposited at an accumulation rate of $0.4 \mathrm{~g} \mathrm{~cm}^{-2}$ year $^{-1}$. Since 1957, a change in the sediment accumulation rate corresponded with a doubling of terrigenous inputs in the top $34 \mathrm{~cm}$ layer of the core. Between 34 and $42 \mathrm{~cm}$, we observed a transition zone with changes in carbonate and phosphorus concentrations that corresponded to a period of approximately 30 years, bioturbation being responsible for a large overestimation of the effective duration of environmental change. Recent terrigenous inputs are associated with a rapid increase in the phosphorus accumulation rate during the same period. The total phosphorus accumulation rate has increased from 300 to $1400 \mu \mathrm{g} \mathrm{cm}^{-2}$ year $^{-1}$ over the five last decades, the latter value being greater than most data found in the literature. Jensen and al. (1995) have measured a phosphorus burial flux of $60 \mu \mathrm{g} \mathrm{cm}^{-2}$ year $^{-1}$ in Aarhus Bay (Denmark). In the Chesapeake Bay, Cornwell et al. (1996) have measured a total phosphorus accumulation rate of $300 \mu \mathrm{g} \mathrm{cm}^{-2}$ year $^{-1}$, and in a review including continental margin sediments, Filippelli (1997) has indicated a maximum phosphorus accumulation rate value of $248 \mu \mathrm{g} \mathrm{cm}^{-2}$ year $^{-1}$ in the St Lawrence Seaway. Higher values have been reported from lake sediments, with total phosphorus fluxes of $200 \mu \mathrm{g} \mathrm{cm}^{-2}$ year $^{-1}$ (Schelske et al., 1988; Rippey and Anderson, 1996), and up to $600 \mu \mathrm{g} \mathrm{cm}^{-2}$ year $^{-1}$ in lake Erie (Schelske and Hodell, 1995), but even these fluxes are significantly lower than the fluxes measured in the present study.

The high values of total phosphorus accumulation rate found in the coastal sediments can be explained in two complementary ways: 1) an increase in inorganic phosphorus inputs due to erosion of basaltic soil, and 2) the increase in organic inputs, including organic phosphorus, due to direct release of untreated anthropogenic wastes (essentially waste waters).

The inorganic phosphorus flux in the bottom layer of the core was mainly carbonate-associated phosphorus, a result which is consistent with our previous finding demonstrating carbonate to be the major sediment reservoir to 1930. The increase in terrigenous and anthropogenic sediment inputs during the last four decades has been associated with a large qualitative change in sedimentary phosphorus forms, essentially the joint increase in $P_{\mathrm{Fe}}$ and $P_{\mathrm{det}}$, which represented $54 \%$ of total phosphorus in recent sediment versus $30 \%$ at the beginning of the century. It must be noted that the six fold increase in $P_{\mathrm{Fe}}$ concentration between 1930 and 1957 coincided with a five fold increase in sedimentary Fe concentrations from $20 \mathrm{mg} \mathrm{g}^{-1}$ to $100 \mathrm{mg} \mathrm{g}^{-1}$ (Harris, 1998). Since the early sixties, building activities on the mountain slopes of Tahiti Island increased soil erosion. Those volcanic soils contain from 0.8 to $3.3 \%$ total phosphorus, only 0.03 to $0.06 \%$ of which as been identified as directly available to terrestrial and aquatic primary producers (Jamet, 1987).

The large change in organic phosphorus concentration represents a major shift in phosphorus deposition. Diagenesis can be responsible for significant mineralization of $P_{\text {org }}$ with sediment depth (Ruttenberg and Berner, 1993; Slomp et al., 1996a, b) and it must be acknowledged that in the absence of pore water phosphorus data the diagenetic contribution cannot be quantitatively assessed. However, results from the literature showed that in coastal environments with comparable $P_{\text {org }}$ concentration levels, diagenetic alteration was moderate and mostly effective in the top $20 \mathrm{~cm}$ layer of sediment (Vink et al., 1997; Louchouarn et al., 1997). Furthermore, the very sharp increase of $P_{\text {org }}$ between 1945 and 1968, followed by almost constant concentrations between 1968 and present, is inconsistent with a progressive action of diagenetic processes. Those arguments suggest that the change observed in phosphorus distribution is revealing a significant increase in $P_{\text {org }}$ deposition rates rather than a diagenetic $P_{\text {org }}$ loss. Furthermore, the decrease in the carbon versus phosphorus ratio in the top sediment layer demonstrates that phosphorus inputs and burial was not proportionally matched by organic carbon. That trend is consistent with an increase in the delivery of phosphorusrich organic material. The coincidence between post1945 increase in $P_{\text {org }}$, decrease in carbonate content and increase in mineral matrix associated $P_{\mathrm{Fe}}$ and $P_{\mathrm{det}}$ further supports the hypothesis that enhanced $P_{\text {org }}$ accumulation rates between 1945 and 1957 could be largely due to enhanced soil erosion. Similar evidence of increased $P_{\text {org }}$ inputs originating from soil erosion has been identified in Australian estuaries (Gerritse et al., 1998a, b). Basaltic 
soils in Tahiti are known to have a high organic phosphorus content (Jamet, 1986), and a recent study of river discharges in Tahiti concluded that organic matter was mostly in particulate form, suspended organic phosphorus concentrations ranging between 1 and $10 \mathrm{mg} \mathrm{L}^{-1}$ (Wotling, 2000).

Additionally, part of $P_{\text {org }}$ is likely to originate from anthropogenic organic material discharge, available mineral surface ensuring a better preservation of organic matter in the sediment (Hedges and Keil, 1995). In the absence of waste water treatment, the Papeava River has been carrying an increasing amount of organic matter originating from growing sewage discharges of the city of Papeete. The four time increase in population and drastic changes in waste production obviously increased the supply of organic material to the lagoon, even though no quantitative historical data exist on the subject (Aubanel et al., 1998).

We estimated that about $60 \pm 10 \%$ of the phosphorus initially deposited at the water-sediment interface were buried in the sediment. Burial efficiency in two other stations in the same area reached similar values (Harris, 1998). The remaining fraction (30 to $40 \%$ ) is mostly released at the sediment-water interface providing dissolved phosphate for primary producers and/or export beyond the lagoon. Lower values of $30-35 \%$ burial efficiency can be currently found in the literature (Jensen et al., 1995), and it is likely that, in Papeete Lagoon sediments, the fast sediment accumulation rates $(1 \mathrm{~cm} \mathrm{y}$ $\mathrm{ear}^{-1}$ ) associated with fine grain-size sediments contributed to a large detrital non-reactive phosphorus burial. However, this calculation based on particle collection over one year must be considered with caution, as it is known that river discharge regimes in Tahiti can be of a very variable nature. As an example, daily discharge during extreme flooding events could be higher than average yearly discharge (Wotling, 2000), demonstrating the importance of short-term events on yearly budgets.

In conclusion, historical reconstruction of sediment and associated phosphorus inputs in a sediment core from the lagoon surrounding the city of Papeete demonstrated that a major alteration occurred in the early sixties. Following the evolution from the bottom to the top of the core, hence from the past to the present, it is possible to distinguish two successive periods.

Prior to 1957, the sediment had a high carbonate content of natural marine origin, and the sediment accumulation rate was $0.40 \mathrm{~g} \mathrm{~cm}^{-2}$ year $^{-1}$. During this period, deposition of terrigenous and anthropogenic products in the Papeete Lagoon was moderate, as were inorganic and organic phosphorus accumulation rates.

From 1957 to the present, sediment supply was mostly of terrigenous origin, and ${ }^{210} \mathrm{~Pb}$ dating showed more than a doubling of the sediment accumulation rate $\left(0.9 \mathrm{~g} \mathrm{~cm}^{-2}\right.$ year $^{-1}$, corresponding to approximately $1 \mathrm{~cm}$ year $\left.^{-1}\right)$. The corresponding $34 \mathrm{~cm}$ thick sediment layer is characterised by high organic and inorganic phosphorus (especially iron bound and detritic phosphorus for the latter) accumulation rates.

Phosphorus sequential extraction proved a suitable and powerful approach for providing information on past environmental changes in a barrier reef lagoon environment such as the Papeete Lagoon. The results obtained with this method provided strong evidence of a significant phosphorus enrichment during the past forty years, mostly due to the combined effect of human induced land erosion and waste water discharge.

\section{Acknowledgements}

Many thanks go to all our colleagues of the ANTROPIC and ECOTROPE programmes supported by IRD and the staff of the IRD Centres in Tahiti and Nouméa. Very special thanks go to S. Pourlier from IRD and M. Treszinski from IPSN who respectively provided major support in phosphorus analysis and radioisotope techniques.

\section{REFERENCES}

Aubanel, A., Payri, C., Tatarata, M., 1998. La Polynésie française, L'état des récifs coralliens en France Outre-Mer. Secrétariat d'état à l'outre-mer, Paris, pp. 59-73.

Bollhöfer, A., Mangini, A., Lenhard, A., Wessels, M., Giovanoli, F., Schwarz, B., 1994. High-resolution ${ }^{210} \mathrm{~Pb}$ dating of Lake Constance sediments: stable lead in Lake Constance. Environ. Geol. 24, 267-274.

Boudreau, B.P., 1997. Diagenetic models and their implementation. Springer-Verlag, Berlin.

Carignan, R., Lorrain, S., Lum, K., 1994. A 50-year record of pollution by nutrients, trace metals, and organic chemicals in the St. Lawrence River. Can. J. Fish. Aquat. Sci. 51, 1088-1100. 
Cornwell, J.C., Conley, D.J., Owens, M., Court Stevenson, J., 1996. A sediment chronology of the eutrophication of Chesapeake Bay. Estuaries 19, 488-499.

Faure, G., 1986, Isotope geology. Wiley and Sons, New York, pp. 363-385.

Fichez, R., Harris, P., Jouen, R., Badie, C., Fernandez, J.M., 1997. Sedimentary records of human induced environmental changes in the Tahiti lagoon. In: Lessios, H.A., Macintyeare, I. (Eds.), Proceedings of the 8th International Coral Reef Symposium, Vol. 2. Smithsonian Tropical Research Institute, Panama, pp. 1833-1838.

Filippelli, G.M., 1997. Controls on phosphorus concentration and accumulation in oceanic sediments. Mar. Geol. 139, 231-240.

Flynn, W.W., 1968. The determination of low levels of ${ }^{210} \mathrm{Po}$ in environmental materials. Anal. Chim. Acta 43, 221-227.

Gabric, A.J., Bell, P.R.F., 1993. Review of the effects of non-point nutrient loading on coastal ecosystem. Aust. J. Mar. Freshwater Res. 44, 261-283.

Gabrié, C., Licari, M.L., Mertens, D., 1995a. L'état de l'environnement dans les territoires français du Pacifique sud, la Polynésie française et l'Ile de Clipperton. Ifen-Ministère de l'environnement, Paris.

Gabrié, C., Payri, C., Hutschings, P., 1995b. The current status of coral reef management in French Polynesia. Mar. Poll. Bull. 29, 26-33.

Gerritse, R.G., Wallbrink, P.J., Murray, A.S., 1998a. Accumulation of phosphorus and heavy metals in the Swan-Canning estuary, Western Australia. Estuar. Coast. Shelf Sci. 47, 165-179.

Gerritse, R.G., Wallbrink, P.J., Murray, A.S., 1998b. Accumulation of phosphorus and heavy metals in the Peel-Harvey estuary in Western Australia: results of a preliminary study. Estuar. Coast. Shelf Sci. 47, 679-693.

Grigg, R.W., Dollar, S.J., 1990. Natural and anthropogenic disturbance on coral reefs. In: Dubinski, Z. (Ed.), Ecosystems of the world, vol. 25, coral reefs. Elsevier, Amsterdam, pp. 439-452.

Harris, P., 1998. Modifications des caractéristiques chimiques du lagon de Papeete liées à l'activité humaine: intérêt des traceurs sédimentaires géochimiques et biogéochimiques dans la reconstitution de l'évolution de l'environnement au cours des 150 dernières années. Thèse de doctorat. Université française du Pacifique, Tahiti.

Hedges, J.I., Keil, R.G., 1995. Sedimentary organic matter preservation: an assessment and speculative synthesis. Mar. Chem. 49, 81-115.

Jamet, R., 1986. Les oxydisols de la Polynésie française. Caractérisation et fertilité. Cah. Orstom, Sér. Pédol. 22, 285-299.

Jamet, R., 1987. Les sols et leurs aptitudes culturales et forestières, Tahiti (Polynésie Française). Collection notice explicative, 107. Éditions Orstom, Paris.

Jensen, H.S., Mortensen, P.B., Andersen, F.Ø., Rasmussen, E., Jensen, A., 1995. Phosphorus cycling in a coastal marine sediment, Aarhus Bay, Denmark. Limnol. Oceanogr. 40, 908-917.

Kenchington, R., Bleakley, C., 1994. Identifying priorities for marine protected areas in the insular Pacific. Mar. Poll. Bull. 29, 3-9.

Koroleff, F., 1976. Determination of phosphorus. In: Grasshoff, K. (Ed.), Methods of seawater analysis. Verlag-Chimie, Berlin, pp. 117-156.
Loring, D.H., Rantala, R.T.T., 1988. An intercalibration exercise for trace metals in marine sediments. Mar. Chem. 24, 13-28.

Loring, D.H., Rantala, R.T.T., 1992. Manual for the geochemical analyses of marine sediments and suspended particulate matter. Earth-Sci. Rev. 32, 253-283.

Louchouarn, P., Lucotte, M., Duchemin, E., de Vernal, A., 1997. Early diagenetic processes in recent sediments of the Gulf of StLawrence: phosphorus, carbon and iron burialrates. Mar. Geol. 139, 181-200.

Lucotte, M., d'Anglejan, B., 1985. A comparison of several methods for the determination of iron hydroxydes and associated orthophosphates in estuarine particulate matter. Chem. Geol. 48, 257-264.

Nittrouer, C., Sternberg, R., Carpenter, R., Benett, J., 1979. The use of $\mathrm{Pb}-210$ geochronology as a sedimentological tool: Application to the Washington continental shelf. Mar. Geol. 31, 297-316.

Rippey, B., Anderson, N.J., 1996. Reconstruction of lake phosphorus loading and dynamics using the sedimentary record. Environ. Sci. Technol. 30, 1786-1788.

Robbins, J.A., Herche, L.R., 1993. Models and uncertainty in Pb-210 dating of sediments. Verh. Internat. Verein. Limnol. 25, 271-272.

Ruttenberg, K.C., 1992. Development of a sequential extraction method for different forms of phosphorus in marine sediments. Limnol. Oceanogr. 37, 1460-1482.

Ruttenberg, K.C., Berner, R.A., 1993. Authigenic apatite formation and burial in sediments from non-upwelling, continental margin environments. Geochim. Cosmochim. Acta 57, 991-1007.

Schelske, C.L., Hodell, D.A., 1995. Using carbon isotope of bulk sedimentary organic matter to reconstruct the history of nutrient loading and eutrophication in Lake Erie. Limnol. Oceanogr. 40, 918-929.

Schelske, C.L., Robbins, J.A., Gardner, W., Conley, D.J., Bourbonniere, R.A., 1988. Sediment record of biogeochemical responses to anthropogenic perturbations of nutrients cycles in lake Ontario. Can. J. Fish. Aquat. Sci. 45, 1291-1303.

Serra, C., Poletiko, C., Badie, C., 1991. Contribution à l'étude de la vitesse de dépôt des sédiments en certains plans d'eau de Polynésie Française, Rapport CEA-R-5558. CEA, Papeete.

Slomp, C., Epping, E.H.G., Helder, W., Van Raaphorst, W., 1996a. A key role for iron-bound phosphorus in authigenic apatite formation in North Atlantic continental platform sediments. J. Mar. Res. 54, 1179-1205.

Slomp, C., Van der Gaast, S.J., Van Raaphorst, W., 1996b. Phosphorus binding by poorly crystalline iron oxides in North Sea sediments. Mar. Chem. 52, 55-73.

Teksöz, G., Yeti, U., Tuncel, G., Balka, T.I., 1991. Pollution chronology of the Golden Horn sediments. Mar. Poll. Bull. 22, 447-451.

Unep/IOC/IAEA, 1995. Manual for the geochemical analyses of marine sediments and suspended particulate matter. Reference methods for marine pollution studies 63. Unep, Paris.

Valette-Silver, N., 1993. The use of sediment cores to reconstruct historical trends in contamination of estuarine and coastal sediments. Estuaries 16, 577-588. 
Vink, S., Chambers, R.M., Smith, S.V., 1997. Distribution of phosphorus in sediments from Tomales Bay. California. Mar. Geol. 139, 157-179.

Wotling, G., 2000. Caractérisation et modélisation de l'aléa hydrologique à Tahiti. Mémoires Géosciences-Montpellier.
Yamamuro, M., Kayanne, H., 1995. Rapid direct determination of organic carbon and nitrogen in carbonate-bearing sediments with a Yanaco MT-5 CHN analyser. Limnol. Oceanogr. 40, 1001-1005.

Zan, L.P., 1994. The status of coral reefs in South Western Pacific Islands. Mar. Poll. Bull. 29, 52-61. 